\title{
Commercial microbial inocula - do they work?
}

\author{
N.B. Fisher Kleinfelder Ecobiological, Australia
}

\begin{abstract}
The important role that soil organisms play in nutrient cycling and plant health has long been recognised in the scientific literature, as well as in the agricultural and mining industries. The market for commercially available inocula of important nutrient cycling microbes aimed specifically at Australian native flora is not developed as agriculture with far fewer products.

Here the author presents the results of a trial utilising commercially available inocula marketed as capable of inoculating native flora. Eleven species of plants commonly found in the Box-Gum Woodlands of central western New South Wales and parts of Queensland were grown under nursery conditions and harvested after 150 days.

Faboideae species trialled were Acacia spectabilis (A. Cunn. ex Benth.), A. doratoxylon (A. Cunn.), Daviesia ulicifolia (Andrews), Pultenaea cinerascens (Maiden and Betche) and Hardenbergia violacea (Schneev.ex Stearn). Treatments included rhizobial, mycorrhizal + bacteria, and combined inoculation, with commercial nursery soil without inoculation as the control.

Preliminary results showed considerable variation between the species. A. spectabilis grew well regardless of treatment and formed root nodules with rhizobia (presumably) resident within the control nursery soil. $\mathrm{H}$. violacea also nodulated when grown in the control treatment, but showed improved growth with both the rhizobial inoculation treatment with the combined treatment. A. doratoxylon, D. ulicifolia and P. cineracsens all showed increased survival and growth with each treatment; i.e. no survival in the control, low survival and poor growth after inoculation with mycorrhizal fungi + bacteria, increased growth again with rhizobial inoculation and markedly improved growth with combined inoculation.
\end{abstract}

In addition to D. viscosa, five eucalypt species were trialled; E. albens, E. conica, E. dawsonii, E. melliodora and E. moluccana. These plants were the subject of two treatments only, the control (as above) and inoculation with mycorrhizal fungi + bacteria. Inoculation actually suppressed growth in the majority of species a phenomenon often recorded in the literature.

Preliminary conclusions show that commercially available inocula can infect target plant species and may provide a useful addition to the tools available for rehabilitation in the absence of available topsoil with a viable microbial population.

\section{Introduction}

The important role that soil organisms play in nutrient cycling and plant establishment and persistence, has long been recognised in the scientific literature as well as in the agricultural and mining industries (Banning et al., 2010). Production of inocula for agriculture is big business both in Australia and internationally. Production of inocula to improve nitrogen fixation in agricultural systems world-wide is estimated to be worth approximately US\$ 150 million annually (Phillips, 2004). Commercial inoculation manufacture is not limited to nitrogen-fixing rhizobium bacteria, but includes both endo- and ectomycorrhizal fungi, plant growth promoting bacteria (PGPB) and fauna such as nematodes.

Australian soils are notorious for being nitrogen and phosphorus deficient (Jasper, 1994) and Australian native flora have evolved a number of strategies to cope with these deficiencies. Symbioses with rhizobia and mycorrhiza, and sometimes both in the case of native legumes, are one such strategy. Native legumes form an important component of native ecosystems both in terms of diversity and biomass (Groves, 1994). And while not unique to Australian ecosystems, most species of native flora form associations with endo- 
ectomycorrhizae (Brundrett, 1991). Soil micro-ecological surveys show that rhizobial symbionts also display a large diversity, some strains are widespread (Lafay and Burdon, 1998) while others have a more limited distribution, or are yet to be described from wider geography (Fisher, 2011).

However the number of products marketed specifically for Australian native flora is low. With very few exceptions inocula consist of generalist strains that will infect as broad a range of plant species as possible to broaden market appeal, usually beyond native flora.

To the best knowledge of this author there is just one rhizobial inoculum specifically targeting native legumes that is commercially available. It consists of three native Bradyrhizobium species sourced from and evaluated for efficacy against 20 Acacia species (Family Mimosoideae) and a smaller range of species in the closely related Faboideae family.

Mycorrhizal-fungi inocula are more prevalent in the market. Almost all available inocula consist of generalist strains of endo-ectomycorrhizal fungi marketed to infect both native and non-native plant species. These inocula are available either consisting solely of endo-ectomycorrhizal fungi, or with other microbes. The more biologically complex formulations of inocula may also contain PGPB with multiple strains of soil dwelling bacteria including Bacillus spp. and Pseudomonas spp., saprophytic decomposer fungi and saprophytic nitrogen fixers. Also increasingly available are products that consist of saprophytic bacteria, with or without compost teas (high nutrient liquids with soil microbes included such as supplied by the Soil Foodweb Institute), naturally occurring enzymes and other products that promote soil microbial action.

In the absence of topsoil for rehabilitation, inoculation with soil organisms may enhance the rehabilitation of mine sites and other landscapes in need of restoration or rehabilitation. But before these products can be used, they must be evaluated for their ability to first infect and promote growth in the target plant species. This trial set out to test the efficacy of two commercially available inocula under nursery conditions that are marketed as growth promoters for native flora.

\section{Trial design}

The trial was conducted on the author's behalf by Grow Local Nurseries at Ellalong in the Lower Hunter Valley of New South Wales. Eleven plant species common to the western coal fields of New South Wales, and classified as white box/yellow box/Blakely's red gum woodland were subjected to four treatments and grown under nursery conditions (see below) (Table 1).

Five leguminous species, five eucalypt species and one non-leguminous shrub species were grown in a commercial potting mix specially formulated for native flora. The potting mix consisted of soil, organic matter such as bark and wood chips, a minor quantity of river sand and some slow-release fertiliser. The mix was used as supplied (i.e. unsterilised). Seeds were locally sourced from commercial seed suppliers. All species were subjected to two treatments. The first was the control which consisted of uninoculated potting mix and the second, potting mix inoculated with the mycorrhizal fungi and potentially beneficial bacteria. Leguminous species were further treated with rhizobial inoculant, and finally the two inoculants combined (Table 1).

The total quantity of potting mix required for each treatment was prepared in sequence, beginning with the control treatment (i.e. no inoculation with soil organisms), potting mix inoculated with mycorrhizal fungi (hereafter mycorrhizal + bacteria inoculum), potting mix inoculated with rhizobia (hereafter rhizobial inoculum), and then potting mix inoculated with mycorrhizal fungi, bacteria and rhizobia (hereafter combined inoculum).

Quantities for each inoculant were as per manufacturers' instructions. The rhizobial inoculum was supplied as three separate pelletised preparations each containing a single Bradyrhizobium strain. These were combined in equal proportions to make a single inoculant that resulted in $45 \mathrm{~g} / \mathrm{m}^{3}$ of Bradyrhizobium spp. 
The inoculant of mycorrhizal fungi was supplied in dry powdered form and incorporated into the potting mix at a rate of $600 \mathrm{~g} / \mathrm{m}^{3}$ resulting in $21 \mathrm{~g}$ of inoculum. Based on manufacturers specifications this equates to 600 endomycorrhizal spores and $>5$ million ectomycorrhizal spores per $20 \mathrm{~g}$. A list of genera comprising the inoculum as supplied by the manufacturer is shown in Table 2.

\section{Table 1 Plant species and soil treatments used in the trial}

\begin{tabular}{|c|c|c|c|c|c|c|}
\hline \multirow[b]{2}{*}{ Scientific Name } & \multirow{2}{*}{$\begin{array}{l}\text { Species } \\
\text { Forms } \\
\text { Association }\end{array}$} & \multirow[b]{2}{*}{ Stratum } & \multicolumn{4}{|c|}{ Treatments } \\
\hline & & & Control & $\begin{array}{c}\text { Mycorrhizal } \\
\text { + Bacteria } \\
\text { Inoculum }\end{array}$ & $\begin{array}{l}\text { Rhizobial } \\
\text { Inoculum }\end{array}$ & $\begin{array}{l}\text { Combined } \\
\text { Inoculum }\end{array}$ \\
\hline Eucalyptus albens & & Canopy & $\checkmark$ & $\checkmark$ & & \\
\hline E. conica & Endo and & Canopy & $\checkmark$ & $\checkmark$ & & \\
\hline E. dawsonii & ecto-mycorrhiza & Canopy & $\checkmark$ & $\checkmark$ & & \\
\hline E. melliodora & & Canopy & $\checkmark$ & $\checkmark$ & & \\
\hline E. moluccana & & Canopy & $\checkmark$ & $\checkmark$ & & \\
\hline Dodenaea viscosa & Endo-mycorrhiza & Shrub & $\checkmark$ & $\checkmark$ & & \\
\hline Acacia spectabilis & $\begin{array}{l}\text { Endo and } \\
\text { ecto-mycorrhiza }\end{array}$ & Small tree & $\checkmark$ & $\checkmark$ & $\checkmark$ & $\checkmark$ \\
\hline A. doratoxylon & $\begin{array}{l}\text { Endo and } \\
\text { ecto-mycorrhiza }\end{array}$ & Small tree & $\checkmark$ & $\checkmark$ & $\checkmark$ & $\checkmark$ \\
\hline Daviesia ulicifolia & Endo-mycorrhiza & Shrub & $\checkmark$ & $\checkmark$ & $\checkmark$ & $\checkmark$ \\
\hline $\begin{array}{l}\text { Hardenbergia } \\
\text { violacea }\end{array}$ & $\begin{array}{l}\text { Endo and/or } \\
\text { ecto-mycorrhiza }\end{array}$ & $\begin{array}{l}\text { Ground } \\
\text { cover }\end{array}$ & $\checkmark$ & $\checkmark$ & $\checkmark$ & $\checkmark$ \\
\hline $\begin{array}{l}\text { Pultenaea } \\
\text { cinerascens }\end{array}$ & $\begin{array}{l}\text { Endo and } \\
\text { ecto-mycorrhiza }\end{array}$ & Shrub & $\checkmark$ & $\checkmark$ & $\checkmark$ & $\checkmark$ \\
\hline
\end{tabular}

Multiple seeds were planted in $200 \mathrm{~mm}$ pots in the week ending October 8, 2011. Legume seeds were pretreated prior to planting by immersing in hot water (approximate temperature $80^{\circ} \mathrm{C}$ ) and soaked overnight. Three replicates of each species per treatment were planted. The trial was not randomised, but treatments were blocked together for ease of handling. Seedlings were thinned to one plant per pot early November and pots were rotated fortnightly. Plants were grown on benches in a shade house ( $70 \%$ sunlight) until late December, when they were placed in full sun (Figure 1). Due to the unusually cool, wet summer experienced in the Hunter Valley during this period, little supplemental watering was required. All plants were harvested by destructive harvest in early April 2012, with stem height, stem dry weight and root dry weight being recorded; only stem dry weight data are presented here. Stems and roots were separated and stems weighed on an Ohaus Pioneer PA512 balance. Nodulation was observed and simple presence/ absence noted. Root samples were taken from each individual replicate, the collected roots combined into a single sample for each species and treatment and sent for analysis of mycorrhizal colonisation. Roots were stained for endomycorrhizal colonisation and the percentage of fine root colonisation calculated.

Legume stem dry weights were analysed for statistical significance by one-way ANOVA, while Euclayptus species and $D$. viscosa stem weights were analysed by Students $t$ - test. 


\section{$3 \quad$ Results}

Survival for three of the legume species, $A$. doratoxylon, $D$. ulicifolia and $P$. cinerascens was not sufficient to present statistical analysis (Table 3 ). All replicates of the remaining eight species survived in all treatments, allowing for statistical analysis.

The mycorrhizal + bacteria treatment did not produce a significant change in stem dry weight. Eucalyptus species and $D$. viscosa recorded an overall trend for a decrease in mean stem dry weights, ranging from $1.08 \%$ for $E$. melliodora (i.e. no change in mean stem weight) to $42 \%$ reduction for $E$. molucanna. E. dawsonnii reduction at $27.45 \%$ was significant $(\mathrm{P}<0.02)($ Table 3$)$. The exception was E. albens with a non-significant increase in mean stem dry weight of $6.8 \%$.

Table 2 Genera comprising the mycorrhizal + bacteria inoculum used in Treatments 2 and 4 , as supplied by the manufacturer

\begin{tabular}{lcl}
\hline Organism & $\begin{array}{c}\text { No. Of Species/ } \\
\text { Strains }\end{array}$ & \multicolumn{1}{c}{ Type/Role } \\
\hline Glomus spp. & 6 & Promiscuous endomycorrhizal fungi \\
Pisolithus sp. & 1 & Promiscuous ectomycorrhizal fungi \\
Scleroderma sp. & 1 & Promiscuous ectomycorrhizal fungi \\
Rhizopogon sp. & 1 & Ectomycorrhizal fungi of Pinus spp. \\
Trichoderma sp. & 3 & Cellulose-degrading fungi \\
Chaetonium globosum & 1 & Cellulose-degrading mould \\
Bacillus spp. & 3 & Plant-growth promoting bacteria \\
Pseudomonas spp. & 2 & Plant-growth promoting bacteria \\
Streptomyces spp. & 2 & Plant-growth promoting bacteria \\
Azotobacter vinelandii & 1 & Saprophytic nitrogen fixer \\
Bradyrhizobium japonicum & 1 & Symbiotic nitrogen-fixer \\
Rhizobium leguminosarum & 1 & Symbiotic nitrogen-fixer \\
\hline
\end{tabular}

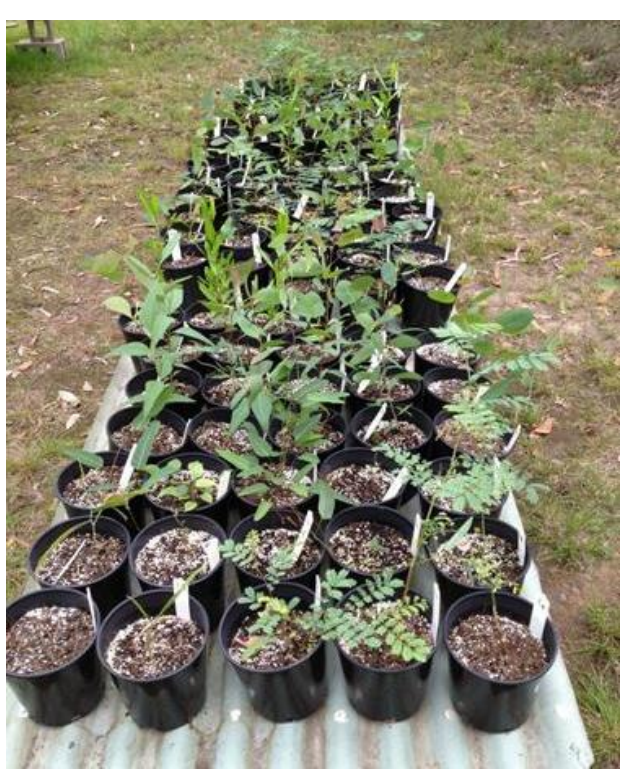

Figure 1 View of the inoculation trial showing the arrangement of the plants when moved from the shadehouse into full sun 
Table 3 Stem dry weights by treatment for the 11 species trialled. Species without standard errors had fewer than three survivors (numbers in brackets following)

\begin{tabular}{|c|c|c|c|c|}
\hline \multirow{2}{*}{$\begin{array}{l}\text { Species } \\
\text { Scientific Name }\end{array}$} & \multicolumn{4}{|c|}{ Stem Dry Weight $(g) \pm$ SE } \\
\hline & Control & $\begin{array}{c}\text { Mycorrhizal + } \\
\text { Bacteria } \\
\text { Inoculum }\end{array}$ & $\begin{array}{l}\text { Rhizobial } \\
\text { Inoculum }\end{array}$ & $\begin{array}{l}\text { Combined } \\
\text { Inoculum }\end{array}$ \\
\hline A. doratoxylon & $0.41(2)$ & $0.17(1)$ & $1.52(2)$ & $3.79(2)$ \\
\hline A. spectabilis & $9.17 \pm 1.97$ & $8.99 \pm 1.76$ & $10.18 \pm 1.18$ & $13.11 \pm 1.25$ \\
\hline D. ulicifolia & (0) & $0.24(1)$ & $0.27(2)$ & $1.98(2)$ \\
\hline H. violacea & $6.48 \pm 2.47$ & $7.13 \pm 1.25$ & $12.55 \pm 0.16$ & $14.59 \pm 1.51$ \\
\hline P. cinerascens & $0.28(2)$ & $0.04(1)$ & $1.94(2)$ & $1.54(2)$ \\
\hline E. albens & $5.39 \pm 1.12$ & $5.75 \pm 1.89$ & NA & NA \\
\hline E. conica & $3.30 \pm 0.53$ & $2.92 \pm 0.74$ & NA & NA \\
\hline E. dawsonii & $3.06 \pm 0.19$ & $2.22 \pm 0.03 *$ & NA & NA \\
\hline E. melliodora & $3.93 \pm 0.08$ & $3.89 \pm 0.60$ & NA & NA \\
\hline E. moluccana & $5.41 \pm 0.32$ & $3.09 \pm 1.37$ & NA & NA \\
\hline D. viscosa & $5.96 \pm 1.04$ & $4.53 \pm 1.16$ & NA & NA \\
\hline
\end{tabular}

* Indicates statistical significance at the $p<0.05$ level.

Legumes did not exhibit significant increases in growth when inoculated with the mycorrhizal + bacteria treatment. Observations cannot be made for $D$. ulicifolia comparing growth between the control and mycorrhizal + bacteria treatments due lack of surviving plants in the control (Tables 3 and 4).
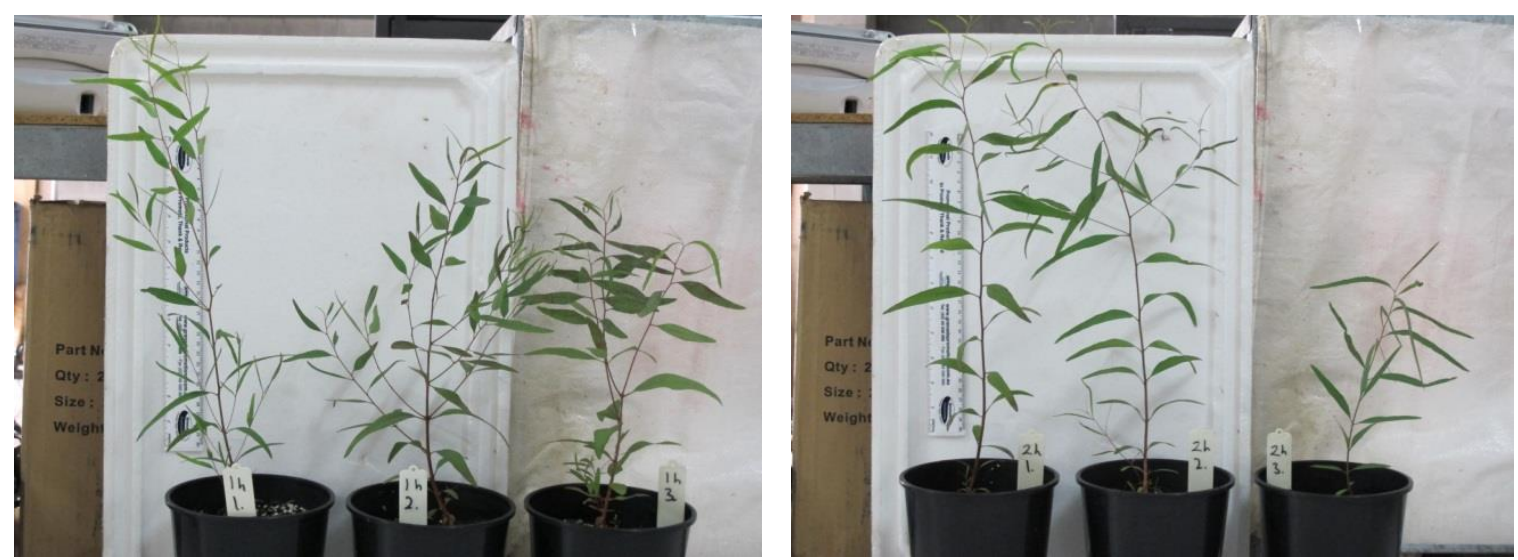

Figure 2 E. conica plants prior to harvesting. Control treatment (left); Mycorrhizal + bacteria treatment (right)

Nodulation was observed from all plants in all treatments, including treatments without rhizobial inoculation. This indicates there was a population of rhizobia already resident within the commercial soil mix. Despite this, inoculation with rhizobial treatment increased plant growth of all legumes. However, of the two species that were statistically analysed, only $H$. violacea produced a significant $(P<0.03)$ increase in stem dry weight when compared to the mycorrhizal + bacteria treatment. Observations of the surviving plants in the remaining species all showed trends for increased stem dry weights when compared to the control and mycorrhizal + bacteria treatments (Table 3 ). The combined inoculation of mycorrhiza + bacteria and rhizobia generally further increased legume growth over the rhizobia treatment alone, although for both $A$. spectabilis and $H$. violacea while this was not significant, visual examination of both these species 
by treatment shows the improved growth throughout the trial (Figure 3 A. spectabilis and Figure 4 H. violacea).

(a)
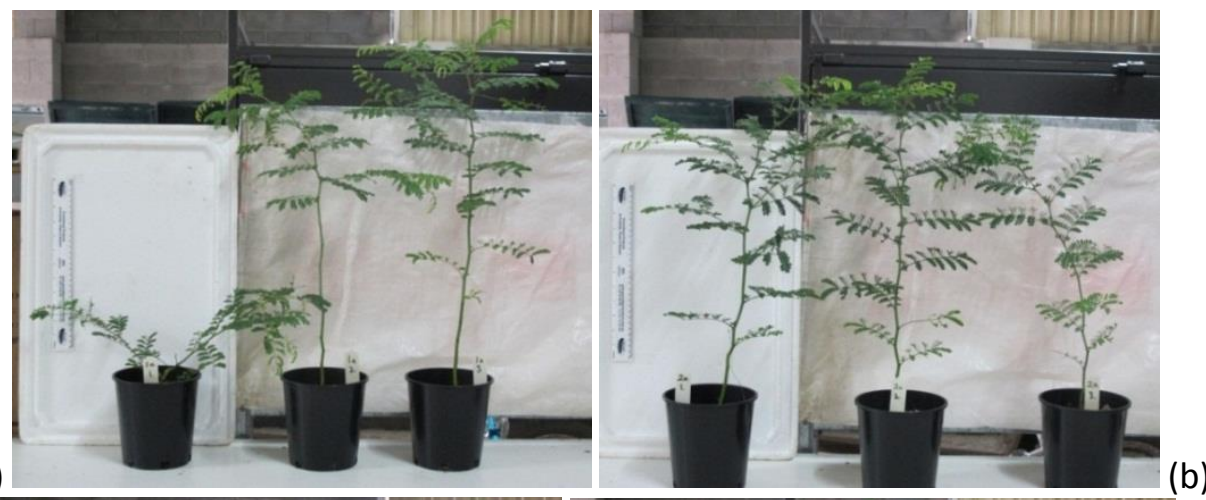

(c)
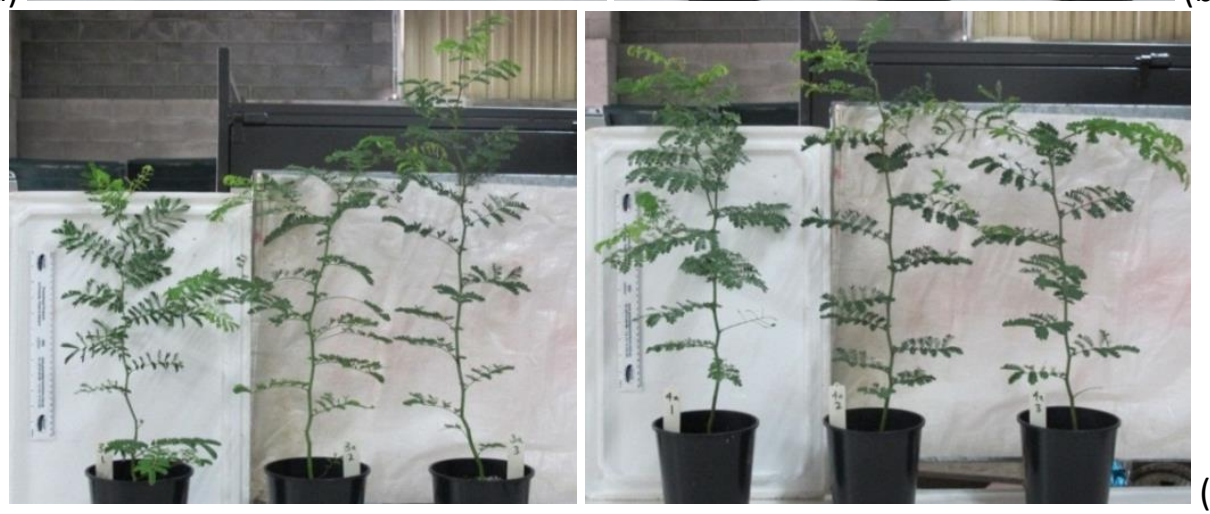

(d)

Figure 3 A. spectabilis showing the four treatments. The treatments are (a) Control, (b) Mycorrhizal + bacteria Inoculation, (c) Rhizobial Inoculation, (d) Combined Inoculation

(a)

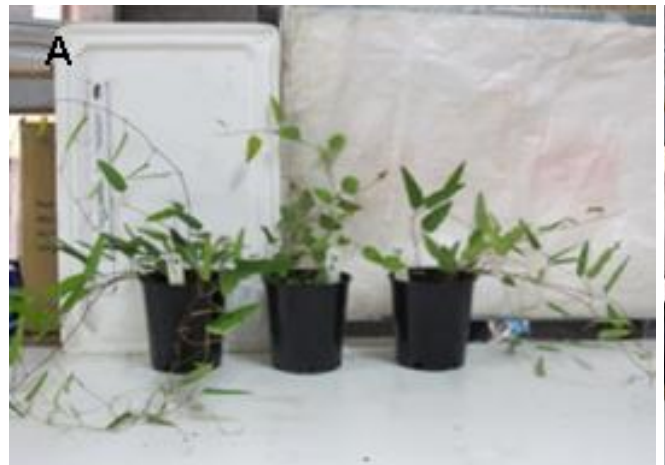

(c)

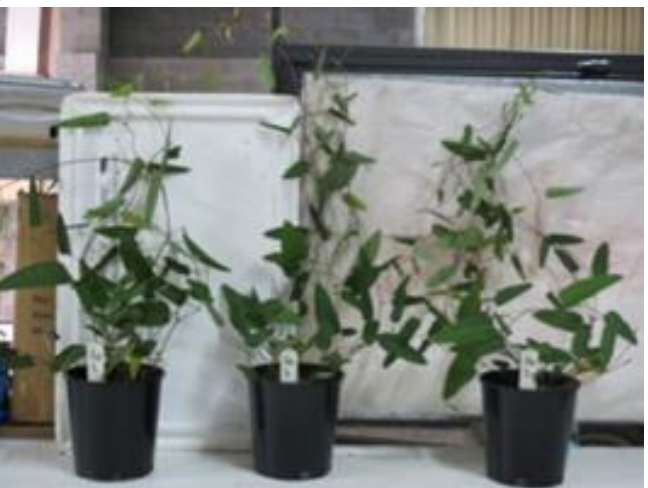

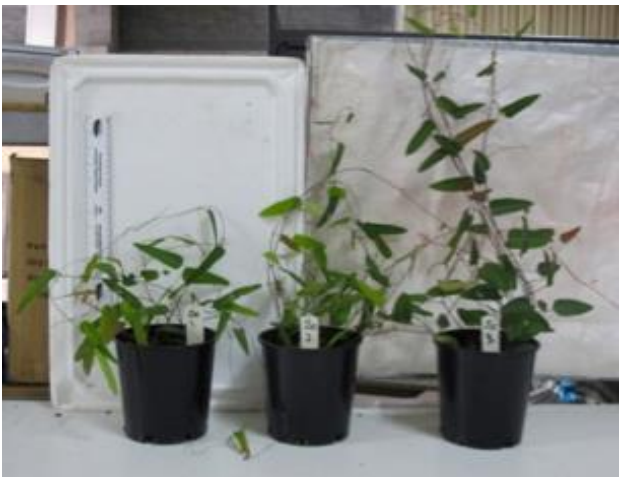

(b)

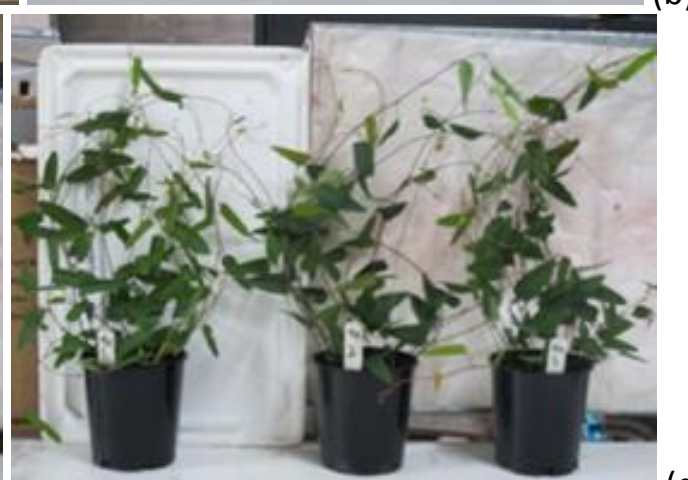

(d)

Figure $4 H$. violacea showing the four treatments. The treatments are (a) Control, (b) Mycorrhizal + bacteria Inoculation, (c) Rhizobial Inoculation, (d) Combined Inoculation 
Determining if the percentage of fine root length (FRL) infected with endomycorrhizal fungi increased with inoculation showed mixed results (Table 4). (NB ectomycorrhizal data was not available at time of writing). The presence of relatively low level of endomycorrhizae infection is indicated by the infection rates in the control treatment for all species (see exception below) and, for the legumes, in the rhizobia only inoculation treatment.

Eight species allowed comparison of FRL infection between treatments. The majority of species ( 5 from 8 ) showed increases from the control to the mycorrhiza + bacteria treatment. Exceptions included $\mathrm{H}$. violacea (the greatest FRL infection for any species for any treatment), A. spectablis, and E. melliodora showed a slight decrease. For the legume species there was not a uniform percentage RLF infection increase from the mycorrhiza + bacteria treatment to the combined inoculation treatment.

Table 4 Fine Root Colonisation of host plants by endomycorrhiza fungi. No sample indicates no survivors to sample (D. ulificfolia) or sample damaged in transit to laboratory ( $A$. doratoxylon and $E$. dawsonii)

Species

Fine Root Colonisation (\%) By Endomycorrhiza

\begin{tabular}{|c|c|c|c|c|c|}
\hline $\begin{array}{l}\text { Scientific } \\
\text { Name }\end{array}$ & Forms Association & Control & $\begin{array}{c}\text { Mycorrhizal } \\
\text { + Bacteria } \\
\text { Inoculum }\end{array}$ & Rhizobia & $\begin{array}{l}\text { Combined } \\
\text { Inoculum }\end{array}$ \\
\hline A. doratoxylon & Endo and ecto-mycorrhiza & No Sample & 14.4 & 4.5 & 9.9 \\
\hline A. spectabilis & Endo and ecto-mycorrhiza & 6.6 & 1.0 & 6.7 & 2.7 \\
\hline D. ulicifolia & Endo-mycorrhiza & No Sample & 10.3 & 1.9 & 34.4 \\
\hline H. violacea & $\begin{array}{l}\text { Endo and/or } \\
\text { ecto-mycorrhiza }\end{array}$ & 71 & 24.1 & 1.8 & 10.3 \\
\hline P. cinerascens & Endo and ecto-mycorrhiza & 12.6 & 16.2 & 14.6 & 48.8 \\
\hline E. albens & Endo and ecto-mycorrhiza & 2.0 & 22.2 & NA & NA \\
\hline E. conica & Endo and ecto-mycorrhiza & 15.3 & 38.3 & NA & NA \\
\hline E. dawsonii & Endo-mycorrhiza & 9.9 & No Sample & NA & NA \\
\hline E. melliodora & Endo and/or ecto-mycorrhiza & 17 & 0.4 & NA & NA \\
\hline E. moluccana & Endo and ecto-mycorrhiza & 0.6 & 26.2 & NA & NA \\
\hline D. viscosa & Endo and ecto-mycorrhiza & 2.8 & 6.0 & NA & NA \\
\hline
\end{tabular}

\section{Conclusions}

This trial demonstrated that the commercially available inocula trialled here were able to both infect native flora and enhance their growth when grown under nursery conditions. Further this trial demonstrated that inoculation with mycorrhizal fungi, bacteria, and rhizobium bacteria of native legumes produce synergistic growth improvements for the two species where survival allowed comparison.

Eucalyptus species form associations with a wide range of mycorrhizal species, with the benefits of this association being demonstrated in glass and shadehouse trials (Arriagada et al., 2009; Madejon et al., 2012). Many Eucalyptus species also display marked growth inhibition when inoculated (Gange et al., 2005; Misbahzzaman and Newton, 2006), and growth suppression was evident in this trial, (though the response was not significant), and due to the presence of the other genera in the inocula, cannot with certainty be attributed only to the mycorrhizae. These and other studies report that the growth suppression is usually transitory and, presumably, those plants with mycorrhizal infection accrue benefits such as improved nutrient uptake, especially phosphorus (Marschner and Bell, 1994) and resilience to drought (Dell, 2002). 
The relatively short growth period in this trial prevented any determination as to the duration of this suppressive effect.

Co-inoculation with rhizobia and mycorrhizal fungi has been reported to greatly increase the growth of agricultural legumes such as pea, Pisum sativum (Geneva et al., 2006), lucerne, Medicago sativa (Ardakani et al., 2009) and cowpea, Vigna unguinculata (Arumugam et al., 2010). One reason for using this particular inoculant was the presence of other organisms including a number of plant growth promoting bacteria, decomposer fungi and mould and a free-living nitrogen fixer. Their presence precludes the assumption that the benefits of co-inoculation can only be attributed to the combination of rhizobia and mycorrhiza. Indeed at least one study into inoculation with multiple plant symbionts and soil dwelling bacteria concludes that selection of the PGPB can be just as important for improving plant growth (Bisht et al., 2009).

The presence of resident populations of soil dwelling organisms can prevent successful establishment of inoculating strains (Jasper, 1994; Slattery and Pearce, 2002). Despite the presence of a resident population of rhizobia as evidenced by background nodulation in the control and mycorrhizal treatments, the use of highly effective strains of Bradyrhizobium (and high levels of inoculation) produced increased stem growth, as seen in the rhizobial only inoculation treatment. Similarly, the mycorrhizal + bacteria treatment also demonstrated treatment effects above the resident population. This suggests that inoculation has the potential to improve plant growth even given the limitations of the trial design. Further analysis being conducted to determine the level of ectomycorrhizal infection will ascertain whether their presence in the inoculum contributed to plant growth.

Despite the relative success of the trials here, these products need further evaluation under field conditions. Field trials with other mycorrhizal inocula have often proven equivocal with little if any observed increase in growth or survival (Bell et al., 2003; So et al., 2011). That Inoculation of Acacias by native rhizobia increase seedling establishment and improve growth has been demonstrated on large-scale field trials, albeit on ex-agricultural land (Thrall et al., 2001). However, for the design of the field trial, approaches will be made to the manufacturer to modify this product by eliminating the Rhizopogon spp., and the agricultural nitrogen-fixers (B. japonicum and $R$. leguminosarum) as these may facilitate the establishment of undesirable exotic flora, such as Pinus spp. (Richardson et al., 2000).

Soil biodiversity and the advantages of resilience and resistance to disturbance that biodiversity imparts, will never be fully restored via inoculation. Non-the-less inclusion of multiple soil dwelling organisms begins to provide greater functional diversity with regards to nutrient cycling.

Given the increasing area of land that is affected by mining, and the importance with which revegetation and rehabilitation is viewed within the mining industry it seems overdue for the research that has been conducted into symbiotic associations and soil microbiology of Australian flora and soils in general to be applied on commercial scales. Multiple strains of rhizobia are available for most if not all legume crops, and inocula can be tailored to suit different soil conditions. The Australian Inoculant Research Group (AIRG) webpage states that it maintains over 1,700 rhizobia strains, many of which are maintained for the eventuality that they may be required for crops or conditions for which no recognised inocula has been formulated. However, in terms of native rhizobia, apart from collections held at research institutions such as universities and the CSIRO, to the best knowledge of this author, no such facility exists for native flora symbionts. The rhizobial inoculant used in this trial is derived from three Bradyrhizobium strains and only has been formally evaluated against 20 species of Acacia but development work appears to have stopped largely due to a lack of demand for the product (J. Stonestreet, 2011, pers. comm.).

This trial was a success under the conditions stipulated demonstrating that the use of these commercial inocula will improve the growth and establishment of native flora. While the plants trialled here were not grown in spoil, they demonstrate that these products have viable soil microbes that will infect target plants species. These products add to the toolbox of techniques that are available to rehabilitate mine sites. However, there are only a limited number of products available, and they may not be suitable for all plants species or all rehabilitation situations. But until such time as the demand for native symbionts drives an increase in the range of organisms contained within a wider number of products, they should be treated as 
an adjunct to, rather than a replacement for the preservation of topsoil as the ultimate source of soil microbes.

\section{References}

Ardakani, M.R., Pietsch, G., Friedel, J.K., Schweiger, P., Maghaddam, A. and Raza, A. (2009) Effect of co-inoculation with rhizobia and mycorrhiza on root parameters of lucerne (Medicago sativa L.) under dry organic farming conditions. International Symposium of Root Research and Applications, RootRAP, 2-4 Sept 2009, Boku, Vienna, Austria.

Arriagada, C., Sampedro, I., Garcia-Romera, I. and Ocampo, J. (2009) Improvement of growth of Eucalyptus globulus and soil biological parameters with sewage sludge and inoculation with arbuscular mycorrhizal and saprobe fungi. Science of the Total Environment, 407, pp. 4799-4806.

Arumugam, R., Rajasekaran, S. and Nagarajan, S.M. (2010) Response of arbuscular mycorrhizal fungi and Rhizobium inoculation on growth and chlorophyll content of Vigna unguiculata Walp Va, Pusa 151. Journal of Applied Sciences and Environmental Management. 14(4), pp. 113-115.

Banning, N.C., Phillips, I.R., Jones, D.L. and Murphy, D.V. (2010) Development of Microbial Diversity and Functional Potential in Bauxite Residue Sand under Rehabilitation. Restoration Ecology. 19(101), pp. 78-87.

Bell, B., Wells, S., Jasper, D.A. and Abbott, L.K. (2003) Field inoculation with arbuscular mycorrhizal fungi in rehabilitation of mine sites with native vegetation, including Acacia spp. Australian Systematic Botany, 16, pp. 131-138.

Bisht, R., Chaturvedi, S., Srivastna, R., Sharma, A.K. and Jouri, B.N. (2009) Effect of arbuscualr mycorrhizal fungi, Pseudomonas flourescens and Rhizobium leguminosarum on the growth and nutrient stats of Dalbergia sissoo Roxb. Tropical Ecology 50 (2), pp. 231-242.

Brundrett, M. (1991) Mycorrhizas in Natural Ecosystems. In Advances in Ecological Research. Begon, M, Fitter, A. H. \& Macfadyen, A. (Eds.) Vol. 21, Academic Press Limited, London, pp. 171-313.

Dell, B. (2002) Role of Mycorrhizal Fungi in Ecosystems, CMU Journal 1(1), pp. 47-60.

Fisher, N.B. (2011) Sustainable reintroduction of the nitrogen cycle post coal mining utilizing the legume-rhizobia symbiosis. Unpublished PhD Thesis, The University of Newcastle, http://ogma.newcastle.edu.au:8080/vital/access/manager/Repository/uon:8582.

Gange, A., Gane, D.R.J., Chen, Y.L. and Gong, M.Q. (2005) Dual colonization of Eucalyptus urophylla ST Blake by arbuscular and ectomycorrhizal fungi affects levels of insect herbivore attack. Agricultural and Forest Entomology, 7 (3).

Geneva, M., Zehirov, G., Djonona, E., Kalayanova, N., Georgiev, G. and Stancheva, I. (2006) The effect of inoculation of pea plants with mycorrhizal fungi and Rhizobium on nitrogen and phosphorus assimilation. Plant Soil Environment, 52(10), pp. 435440.

Groves, R. H. (1994) Australian Vegetation. 2nd edition, Cambridge University Press.

Jasper, D.A. (1994) Bioremediation of agricultural and forestry soils with symbiotic micro-organisms. Australian Journal of Soil Research, 32, pp. 1301-1319.

Lafay, B. and Burdon, J.J. (1998) Molecular diversity of rhizobia occurring on native shrubby legumes in south eastern Australia, Applied and Environmental Microbiology. Vol. 64(10), pp. 3989-3997.

Madejón, E., Dornmila, A.I., Madejón, P., Baker, A.J.M. and Woodrow, I.E. (2012) Biosolids, mycorrhizal fungi and Eucaltpts for phytostabilization purposes if sulphidic mine tailings. Agroforestry Systems. 84(3), pp. 389-399.

Marschner, H. and Bell, B. (1994) Nutrient uptake in mycorrhizal symbiosis. Plant and Soil. 159 (1), pp. 89-102.

Misbahzzaman, K. and Newton, A. (2006) Effect of dual arbuscular-ectomycorrhizal inocualtion on mycorrhizal formation and growth in E. camaldulensis Dehn. seedlings under different nutrient regimes. International Journal of Agriculture \& Biology, 8(6), pp. 848-854.

Phillips, P.W.B. (2004) An economic assessment of the global inoculant industry. Online, Crop Management.

Richardson, D.M., Allsopp, N., D’Antonio, C.M., Milton, S.J. and Rejmánek, M. (2000) Plant invasions - the role of mutualisms. Biological Reviews, Vol. 75, pp. 65-93.

Slattery, J. and Pearce, D. (2002) Inoculants and Nitrogen Fixation in Vietnam (ed. D Herridge) ACAIR Proceedings 109e.

So, T., Ruthroff, K.X. and Dell, B. (2011) Seed and seedling responses to inoculation with mycorrhizal fungi and root nodule bacteria: implications for restoration of degraded Mediterranean-type Tuart woodlands. Ecological Management \& Restoration, 12(2), pp. 157-160.

Thrall, P., Murray, B.R., Watkin, E.L.J., Woods, M.J., Baker, K., Burdon, J.J. and Brockwell, J. (2001) Bacterial partnerships enhance the value of native legumes in the rehabilitation of degraded agricultural lands. Ecological Management \& Restoration: 2(3), pp. 233-235. 
